\title{
逆極性並列接続した真空トリガギャップの始動特性
}

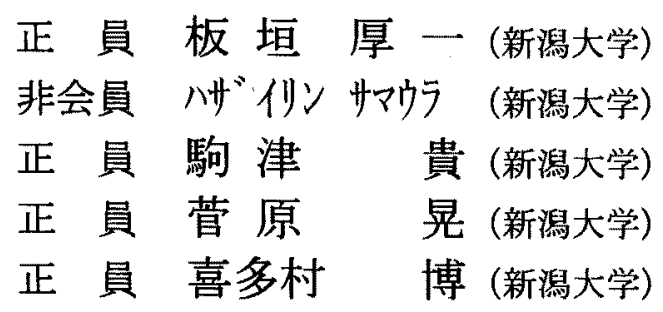

\section{Switching Characteristics of Parallel Connected Triggered Vacuum Gaps with Reverse Polarity in Each Gap}

\author{
Kouichi Itagaki, Member, Hazairin Samaulah, Non-Member, Takashi Komatsu, Member, \\ Akira Sugawara, Member, Hiroshi Kitamura, Member ( Niigata University )
}

\begin{abstract}
The switching characteristics of parallel triggered vacuum gaps(TVGs)were investigated experimentally. Since the switching characteristics of a single TVG were strongly influenced by main voltage polarity in which $(P)$ mode ( the trigger was put in the cathode of main electrodes) gave short switching time and (Q) mode (the trigger was put in the anode of main electrodes ) gave long switching time, we arranged two TVGs in parallel in which the trigger was located in the anode and the cathode of each gap for nullifying or reducing main voltage polarity effect.

The switching time of parallel TVGs was similar in case of a single TVG of (P) mode. The switching probabilities of parallel TVGs were strongly influenced by variations of gap length and trigger current when either of TVGs did not fire in the case that main gap length was longer than $3 \mathrm{~mm}$ and trigger current was less than $10.7 \mathrm{~A}$.
\end{abstract}

キーワード：逆極性並列接続, 真空トリガギャップ, 始動時間, 極性効果

\section{1. まえがき}

高電压工学, 電力工学, 高温プラズマ工学等多くの分野 において、コンデサ放電によるインパルス電圧・電流が よく用いられている。この場合、インパルス電圧・電流制 御用ギャップスイッチが重要な役割をはたしている。

例えば，気中トリガギャップ(1)，(2) は，絶縁破壊電压 に近い主電圧に対しては，非常にすぐれた始動特性を示す。 しかし，主電王が低下するに従ってその始動特性は急速に 悪くなり，絶縁破濖電压の30\%程度の主電圧ではギャッフ の始動が不可能になる。

真空トリガギャップ(3) は, 気中トリガギャップと比较 して, 次の利点がある。（1）始動特性がよい。すなわち, 1 数 $10 \mathrm{kV}$ 広範囲の主電圧で始動時間が $0.5 \mu \mathrm{s}$ 程度以 下の一定値に保たれる。（2）真空アーク電圧は $20 \mathrm{~V}$ 程度 と低いので, 通電時の損失が少ない。（3）電流零点後の 主電極間の絶縁回復が速いので, 繰り返し頻度の大きい用 途 (4)，(5) にも適している。（4）主電極間で大電流放電
を行うと辐音を発生するが，真空トリガギャップは，静か である。（5）主電極間距離が $1 \mathrm{~mm} ゙ も 10 \mathrm{kV}$ 程度の絶縁耐 圧をもつので，小形化できる。

短所としては，主電極間に刋加する電圧極性によって， 始動時間が著しく異なることである(6) 一(11)。除極侧から トリガする方が，陽極側からトリガするよりも始動時間は 短い。これを，始動時間の極性效果と称することにする。 真空トリガギャップの始動は, 次のように考えられる。 トリガ放電によってプラズマが主電極間に生成され, 主電 栖間電界や泌度勾配による拡散により荷電粒子が移動する。 このとき電子やイオンが中性ガス分子や電極に衝外し電極 間プラズマ密度を增大させ，主電極間の絶縁破壊を引き起 こし，主放電を誘発し，真空トリガギャップが始動すると 思われる。

陽極側からトリガした場合，トリガ電極から放出された 電子は陰極への進展を抑えられてしまう。つまり, 正イオ ンは陰極側へ移動するが, 質量の軽い電子は負のポテンシ ヤル障壁で押し返されることになる。そこで, イオンは雨 
極栍拡散ではなくドリフト速度程度のゆっくりした速さで 移動することになる。このため主電極間の放電チャネルの 形成が遅くなり，その結果として始動時間が遅くなり，始 動しにくくなると考えられる。

陰極側からトリガした場合には，主電極によるポテンシ ヤル障壁はなく、トリガ放電により生じたカソードスポッ トがそのまま主放電のカソードスポットになるなどの理由 から，始動時間が速く，始動が容易になるものと思われる。 真空トリガギャップを回路に組み込んで使用する場合, 印加電什極性が分かっている場合には，始動時間が短くな る電王極性を選択しておけば問題はない。しかし，印加電 圧極性が不明の保護ギャップ装置などに応用しようとする と，始動時間が長くなる可能性もあり具合が悪い。この点 を改善するために，著者らは，

（1） 2 個の真勂トリガギャップを直列接続する。

(2) 陰極と陽極の両電極にトリガ電極を取り付ける。 の2つの方法について検討してきた。（1）は，極性奻果 ができるだけ少なくなるように2 個の真空トリガギャップ を接続するものである。著者らの実験(12)では，始動時間 は長くなるが極性効果をある程度軽減できることを示した。

（2）では，極性効果が無く，始動時間が0.5 us程度の值 が得られた ${ }^{(13)}$ 。しかし, 電極構造が複雑で, 主電極間距 離を変えることには，困難を伴う。

（1），(2）とは別の方法として，真空トリガギャッ プを逆極性並列接続することが考えられる。この場合，主 電極間の䀦加電圧極性にかかわらず，始動特性のよい陰極 側からトリガするギャップが先に始動するので，始動時間 の極性効果が隇少することが期待される。

真空トリガギャップを同極性で並列接続したときの始動 特性については, 著者らはすでに検討した。この場合には,

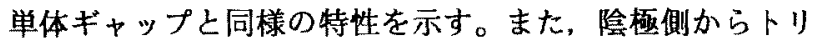
ガした始動しやすい電圧極性の場合の各ギャップを流れる 電流は，平等に分流されるをすでに明らかにしたは14)。し かし，逆極性並列接続した真空トリガギャップの始動時間, 各ギャップを流れる電流などについては，ほとんど不明で ある。

本研究では，逆極性並列接続した真空トリガギャップの 始動特性について実験的に検討した。その結果，逆極性亚 列接続した真空トリガギャップの始動時間は，主電王10〜 $20 \mathrm{kV}$ ，トリガ電流59Aで，約0.4 山s一定值を示した。この 值は，始動特性が良好な陰極側からトリガした単体ギャッ プの始動時間に近いことを明らかにした。

\section{2. 実倹可路と実蛤方法}

真空トリガギャップ（以下，TVG と略記する）を陰極あ るいは陽極側からトリガする場合に，トリガ電極の電圧印 加極性により，4通りのモードがある。しかし，陰極ある いは陽極側からトリガする場合の始動特性に比較して，卜 リガ電極印加電王が正あるいは負極性であっても，始動特

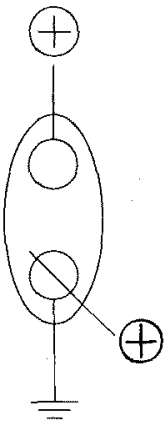

(P)

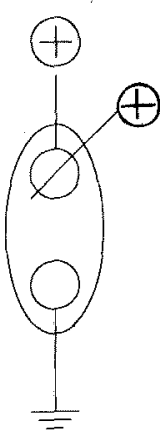

(Q)

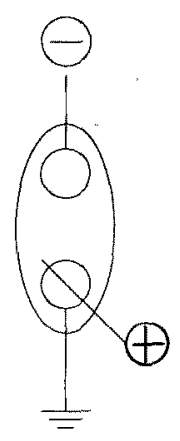

( R)

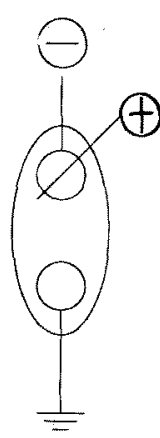

( S )
図 1 単体真空トリガギャップの接続方式

Fig. 1. Four mechanical connection modes of a TVG with positive trigger pulse.

性には大きな影響を及ぼさないことが知られている(2)。 そこで，本研究では，トリガ電極印加電任を正極性にして いる。

トリガ電極に正極性の電圧を印加した時の, TVG の接続 方式を図 1 に示す。（P）と（S）モードは陸極側からト リガするもので，始動特性は（Q），（R）モードの場合 よりは良い。（P）と（S）モードは，ほぼ同程度の始動 特性をもつ。（Q），（R）モードは，陽極側からトリガ するもので，始動特性は悪く，（Q），（R）モードは， ほぼ同程度の始動特性をもつ (13)。ここでは，(P) と

(Q) モードを並列接続する。

実殹に使用した真空トリガギャップの概略を図 2 に示す。 以前に使用したものと同形の封じ切り形(12)のものである。 絶縁容器は外径 $83 \mathrm{~mm}$, 長さ200mm の円筒状のアルミナで構 電流波形の一例を図 4 に示す。図 4 (a) は,トリガコン

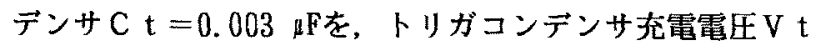
$=15 \mathrm{kV}$ にて,トリガ抵抗 $\mathrm{R} \mathrm{t}=270 \Omega$ とパルストランス を介して，放電させたときのTVG1のトリガ電流波形である。

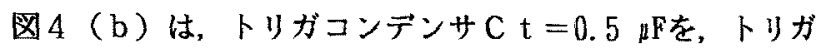

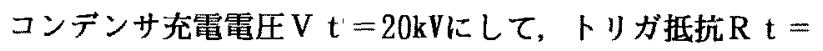
$350 \Omega$ 凡して, 放電させたときのTVG1のトリガ電流であ る。

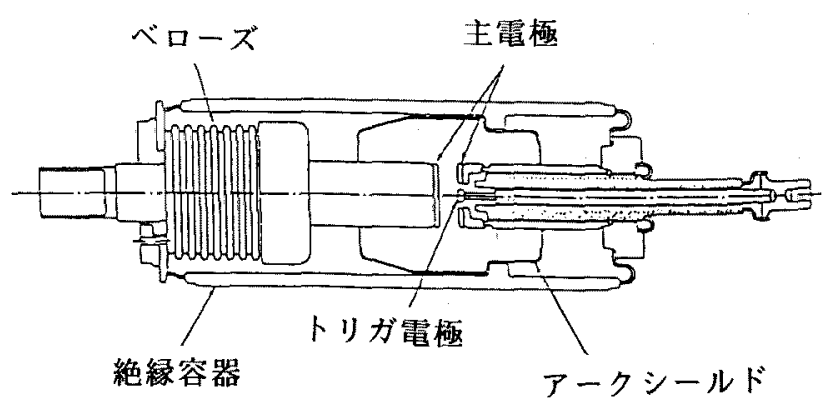

図2 真勂トリガギャップの概略図

Fig. 2. Schematic diagran of triggered vacuum gap. 


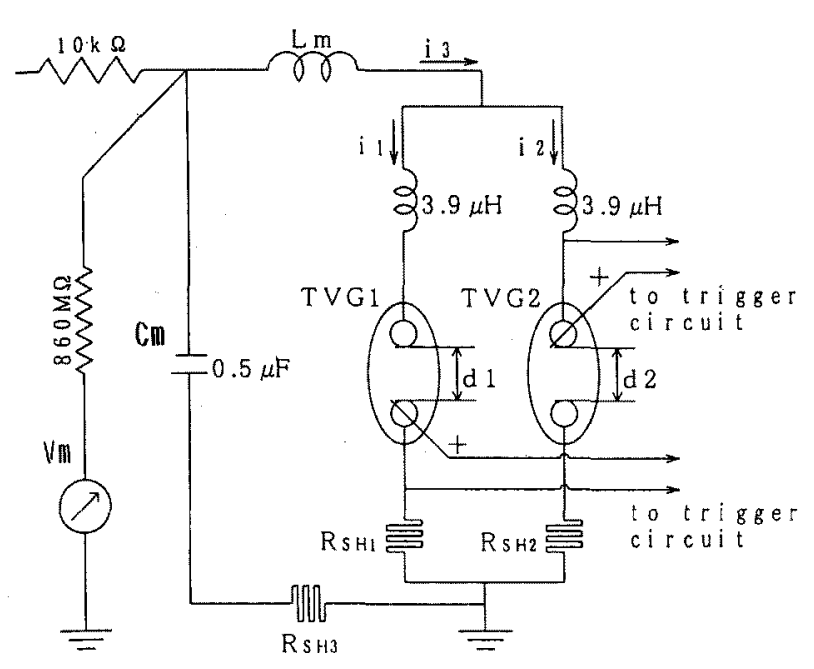

図 3 実験回路

Fig. 3. Experimental circuit of parallel TVGs.

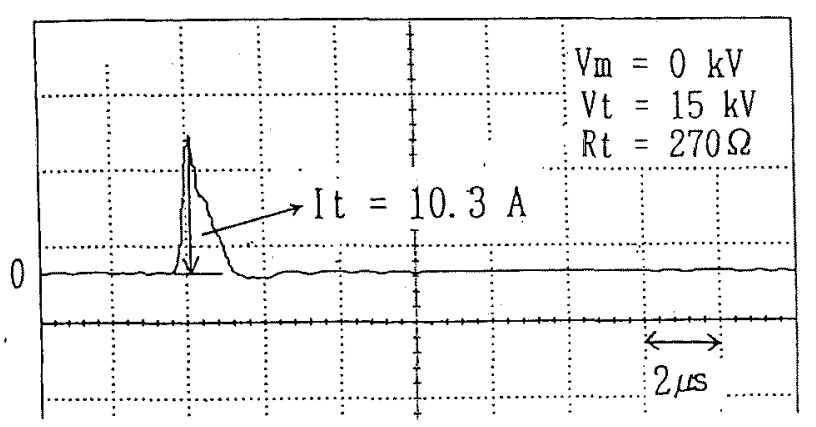

（a）継続時間の短いトリガ電流

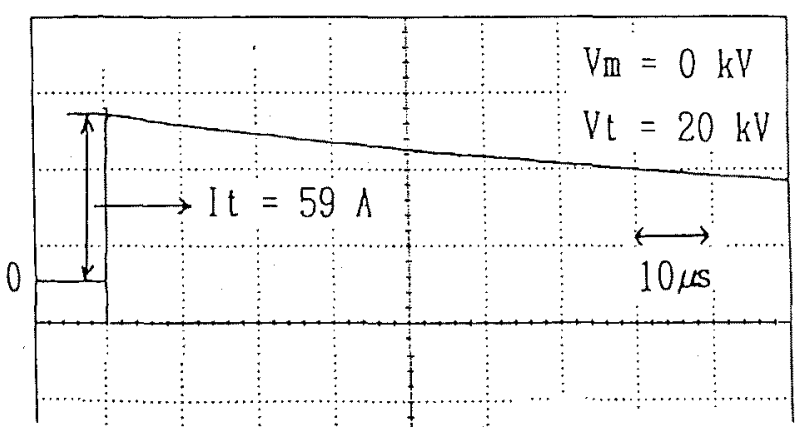

（b）継続時間の長いトリガ電流

図 4 トリガ電流波形の一例

Fig. 4. Typical examples of trigger current.

筆者らの実釦によると, トリガ電流の継続時間が長く， 電流值の大きいトリガほどTVG の始動特性が良好である。 主電流波形の観测と始動確率の測定には，TVG が動作しな い場合も必要なので, 図 4 （a）のトリガ電流を使用した。 また, 始動時間の测定では, TVG が始動していることが必 要なので，図4（b）のトリガ電流を使用した。

主コンデンサ $\mathrm{Cm}$ の充電電圧は 4.0 ～30kVの範囲であり， トリガコンデンサ C t 充電電圧は15～20kVの範囲である。 TVG1とTVG2の各々を流れる電流 $I_{1} ， I_{2}$ と主電流 $I_{3}$
はシャント抵抗 $\mathrm{R}_{\mathrm{SH} 1}, \mathrm{R}_{\mathrm{SH} 2}$ と $\mathrm{R}_{\mathrm{SH}_{3}}$ で, トリガ電流波 形はロゴスキーコイルで検出し, 積分回路を通しオシロス コープで観察した。

各コンテンサの充電時間, トリガ投入のタイミングなど を制御して，20秒に 1 回の割合で繰り返し放電を行った。

\section{3. 実駼吉果と考察}

<3. $1>$ 主電流波形 主電圧を変化させたときの 主電流波形の一例を図 5 に示す。図5（a）は主電王Vm が 4.3kV と低い場合で, 陰極側からトリガするTVG1のみ が動作して，陽極側からトリガするTVG2は始動していない。 TVG1の電流 I 1 と主電流 I 3 は半波である。図 5 （b）は, TVG1とTVG2を流れる電流 $\mathrm{i}_{1}$ と $\mathrm{i}_{2}$ が半サイクル毎に流れ ている。 $\mathrm{I}_{3}$ は, 減衰振動電流で，10サイクル継続してい る。図 5（c）では，TVG1とTVG2の電流が途中で，同方向 に流れている例である。この場合も，I っとしては，減哀 振動電流である。

トリガ電流を变化させたときの主電流波形の一例を図 6 に示す。図6（a）では,トリガ電流 $1 \mathrm{t}$ が10.3A と少な いので, TVG1のみが始動しTVG2は動作していない。図6

(b) では, I t が36.6A と大きいので, TVG1とTVG2の両 方が始動している。

逆極性並列接続した各真空トリガギャップの電流が図 5 (b) や図6 (b) に示すように，半サイクル毎に交互に 流れる現象は，真空トリガギャップの絶縁回復と始動時間 の極性効果に原因があると考えられる。真空トリガギャッ プの絶縁は，数住以下で回復する(15)〜(17)。図5（a） のTVG1の電流 $\mathrm{i}$ ，は，主電厌が $4.3 \mathrm{kV}$ と低いので, 最初の 電流零点で絶緣回復し，電流は最初の半サイクルしか流れ ない。

主電王が高い図 5 （b）の電流 $\mathrm{i}_{1}$ は, 最初の半サイク ル後に零になっている。この時点で, TVG1の電極極性が始 動しにくい（R）モードとなることと，TVG2が始動してギ ヤップ間電圧が咸少するためである。

TVG2はトリガ時に始動しないで，TVG1に電流が流れてか ら半サイクル後に始動している。トリガ時には，始動しに くい（Q）モードであるので，始動しない。TVG1の電流半 サイクル後のTVG2の電極極性は，（S）モードになるので 始動する。

トリガ電流は 2 山程度しか継続しないので，（S）モー ド時にはトリガ電流は流れていない。しかし，トリガ放電 による主電極表面の加熱状態が維持され，これが原因で

（S）モード時に始動すると思われる。実際に，TVG2のト リガ回路を取り去ると，TVG2の主電流は流れず，図6（a） のような電流波形が観測される。また，図4（b）の継続 時間の長いトリガ電流の場合には, 図 5 (b), 図6（b) の電流波形がよく観測された。

このように，逆極性並列接続した真空トリガギャップの 主電流は減哀振動電流となっていても，TVG1とTVG2に流れ 


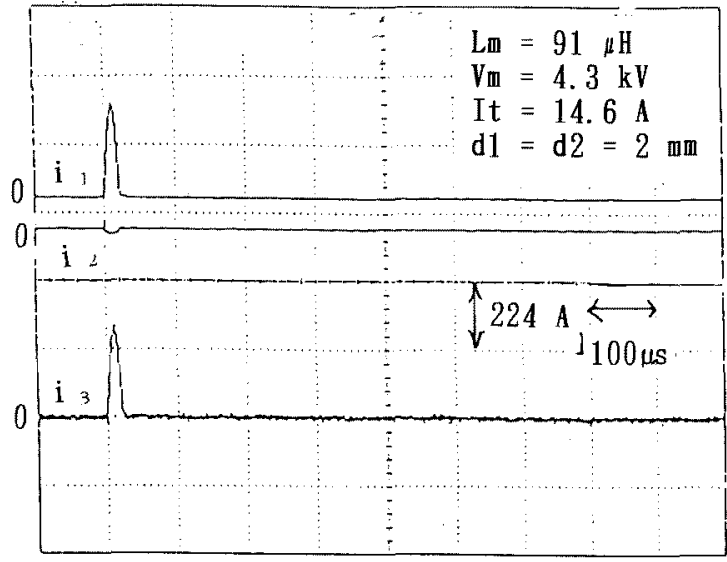

(a) $\mathrm{V} \mathrm{m}=4.3 \mathrm{k} \mathrm{V}$

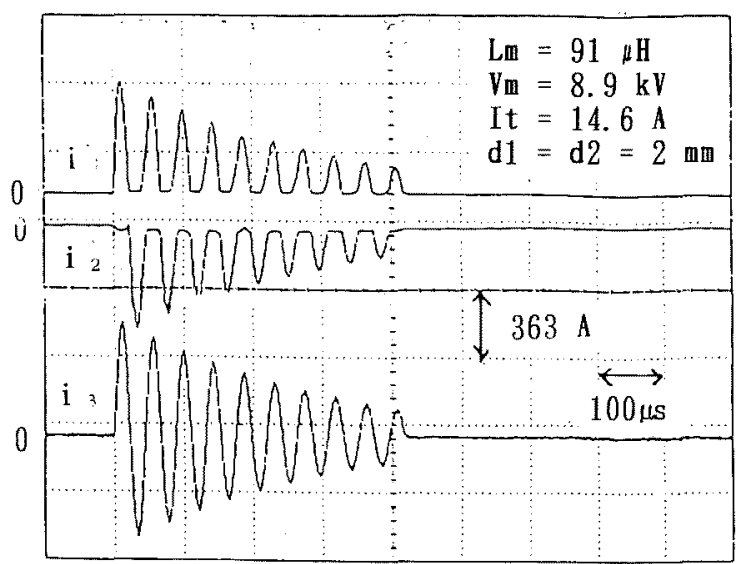

(b) $\mathrm{Vm}=8.9 \mathrm{k} \mathrm{V}$

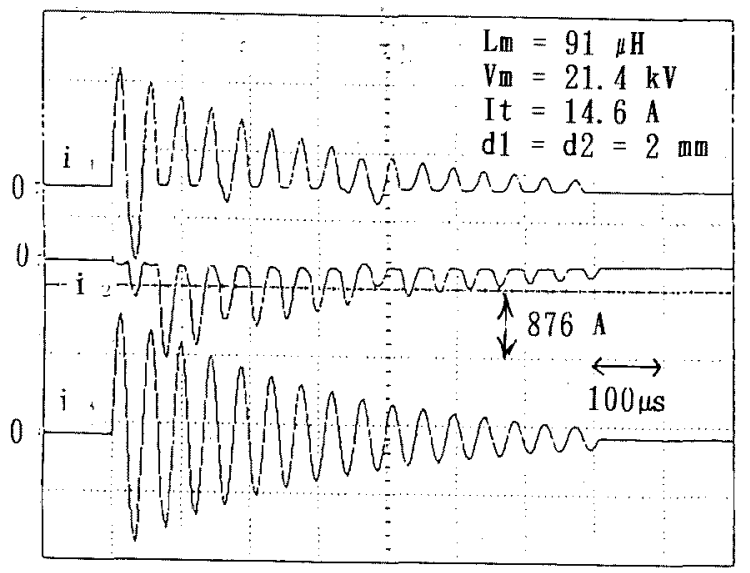

(c) $V \mathrm{~m}=21.4 \mathrm{k} \mathrm{V}$

図 5 主電圧を変えた時の主電流波形の一例

Fig. 5. The typical examples of main current with varing main voltages.

る電流は，半波毎に交互に流れていることが多い。

<3，2>始動確染 トリガしたときに，真空トリガ ギャップが始動して, 主電流が流れるかどうかは, 確率的 にきまる。そこで, 同一条件で, 10回の実験を絽り返して, 始動確率を測定した。

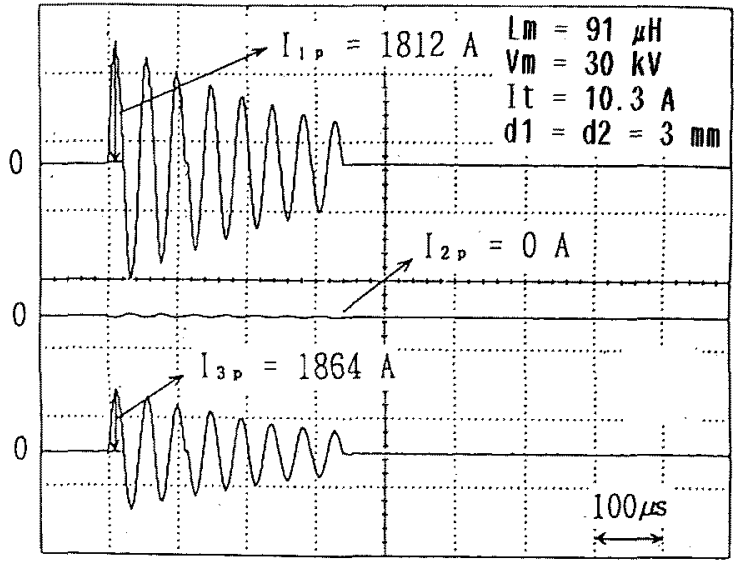

(a) I $\mathrm{t}=10.3 \mathrm{~A}$

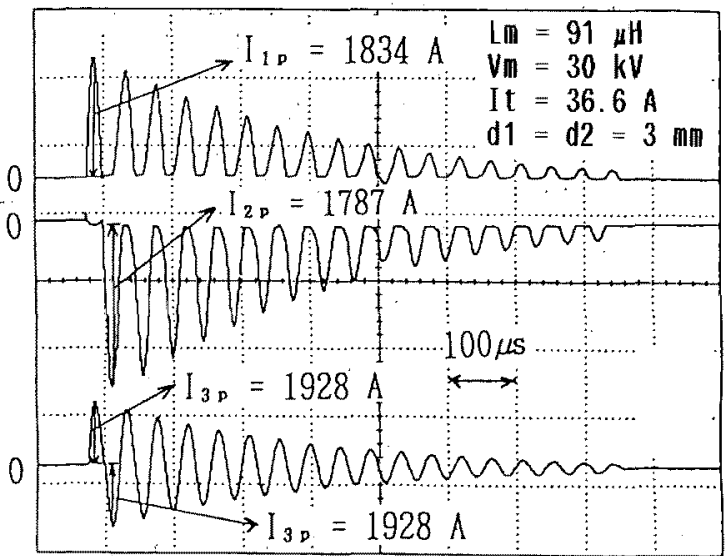

(b) $\mathrm{I} t=36.6 \mathrm{~A}$

図 6 卜リガ電流を変えた時の主電流波形の一例 Fig. 6. The typical exemples of main current with varing trigger current.

逆極性亚列接続したTVG の始動確率としては, 電流を平 等に分担する意味から，TVG1とTVG2の始動確率は，ある程 度バランスしていることが望ましい。

始動確率に及ぼす主電極ギャップ長の影掣を図 7（a ） に示す。逆極性並列接続時のTVG1の始動確率は, ギャップ 長 1 〜 10mmの範囲で100 \%である。しかし, TVG2の始動確 率は, ギャップ長 $3 \mathrm{~mm}$ 以上では $0 \%$ ある。

逆極性亚列接続したTVG の始動確率は, 図6（a）から も予想されるように，始動確率の高いTVG の特性に支配さ れる。図7（a）における逆極性並列接綄したTVG の始動 確摔は，TVG1の始動確率と同じで，100％である。

TVG の始動特性としては, トリガ電圧を甽加してから, トリガ電流が流㧈るまでの特性も重要である。本実殹条件 では, 逆極性並列接続した 2 個のTVG にトリガ電圧を印加 したとき,トリガ電流がほぼ同時に流れることを確認して いる。

TVG の始動確率に及ぼすトリガ電流の影響を図 7（b ） に示す。トリガ電流10.3〜 36.6A の範囲で. TVG1の始動確 率は100\%である。TVG2の始動確率は, トリガ電流ととも に增加する。逆極性並列接続したTVG1とTVG2をあわせた始 


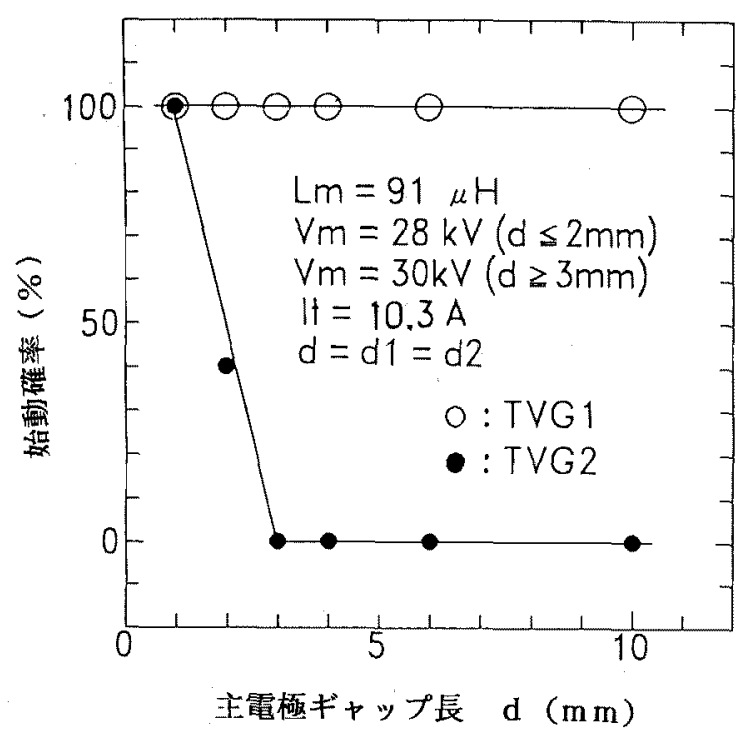

（a）始動確率と主電極ギャップ長の関係

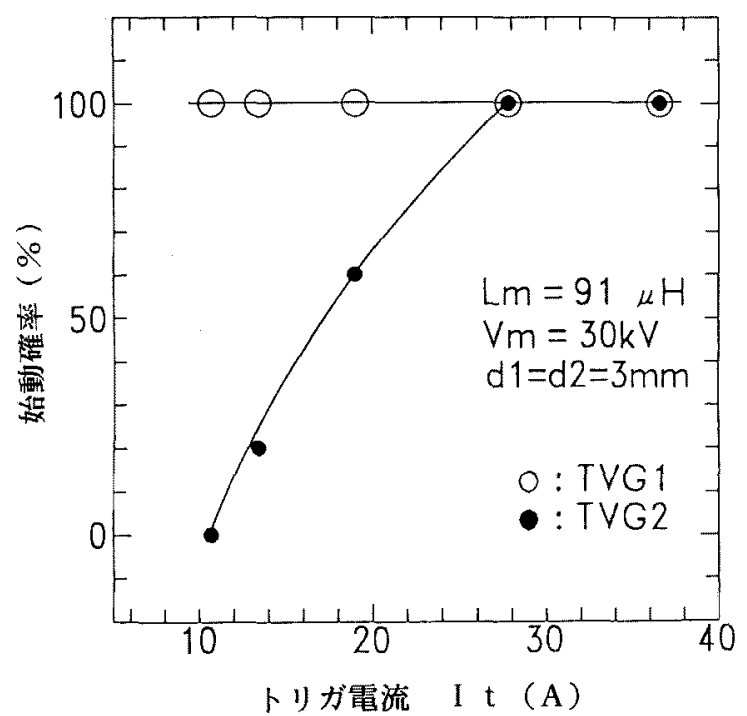

（b）始動確率とトリガ電流の関係

図 7 逆極性亚列接続時の真空トリガギャップの 始動確率

Fig. 7. Switching probability of a TVG as a function of main voltage and trigger current.

動確摔は，TVG1の始動確率は同じで，100％である。

これらのことから，始動しにくい電極極性のTVGの始動 確率を大きくするためには主電極のギャップ長を短くして， トリガ電流を大きくする必要がある。

く3. 3> 始動時間 真空トリガギャップの始動時 間は, 装置の信頼性の向上や他の周辺機器との同期を考え ると、極力小さいことが望ましい。

园 8 にTVG 始動時のトリガ電流と主電流波形の一例を示 す。トリガ電流波形は网 4 （b）の場合より，テイル部の 减衰が大きくなっている。図4（b）のトリガ電流は，主

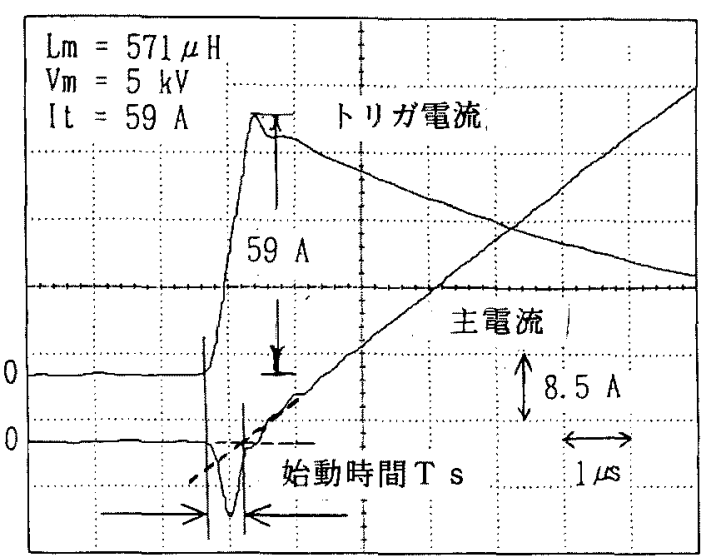

図 8 始動時間の定義

Fig. 8. Switching time between the initiation of the trigger current and the initiation of the main current.

電流なしの場合である。図8のトリガ電流には,ギャップ を介して，主電流が流れ込むために，図4（b）とは異な ったトリガ電流波形になっている。

トリガ電流が流れ始める時刻から, 主電流が正方向に立 ち上がる時間 $1 \mu \mathrm{s}$ 程度の直線部分（図 8 中の点線）を外挿 し、電流が零になる時刻（図 8 中の矢印）までの間を始動 時間Tsと定義した。トリガ電流が流れ始める時刻としては， オシロスコープ上のトリガ電流波形を観测して, トリガ電 流が零ラインから離れ始める時刻とした。この方法は簡便 であり，かつ読みとり誤差を少なくできるものと考えてい る。同一条件で10回測定し，その算術平均值を始動時間と した。

始動時間は, 主電王, 主電流上昇率, トリガ電流などの 回路条件によって変化する。主回路インダクタンスを変え る場合には，主電圧と主電流上昇率の効果を分離する必要

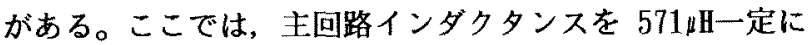
して実験した。

主電厌と始動時間の関係を図9（a）に示す。単体ギャ ップの ( $\mathrm{P})$ モード (狯極例からトリガ) では, 主電圧 5 〜20kVの範囲で，的 $0.4 \mu \mathrm{s}$ 一定の始動時間を保っている。 このときの始動時間のバラッキ(13)は，47〜98\%である。

（Q）モード（陽極側からトリガ）では, 主電压の増加之 ともに，始動時間は減少する。しかも，(P) モードの場 合よりも，始動時間は長く，主電圧 $15 \mathrm{kV}$ 以下では始動しな い。この㑯向は，他の実験結果 ${ }^{(6)}$ とも一致している。す なわち，始動時間の極性効果が顕著に現れている。

（P）と（Q）モードを並列接続続した（P）+（Q） モードの始動時間は，（P）モードの場合にほぼ一致して いる。しかし，この場合の始動時間のバラッキは，89〜 $228 \%$ \%, 単体ギャップの（P）モードょり増加している。 この理由は, いまのところ不明である。

トリガ電流と始動時間の関係を図9（b）に示す。単体 ギャップの（P）と（Q）モードでは，トリガ電流の増加 


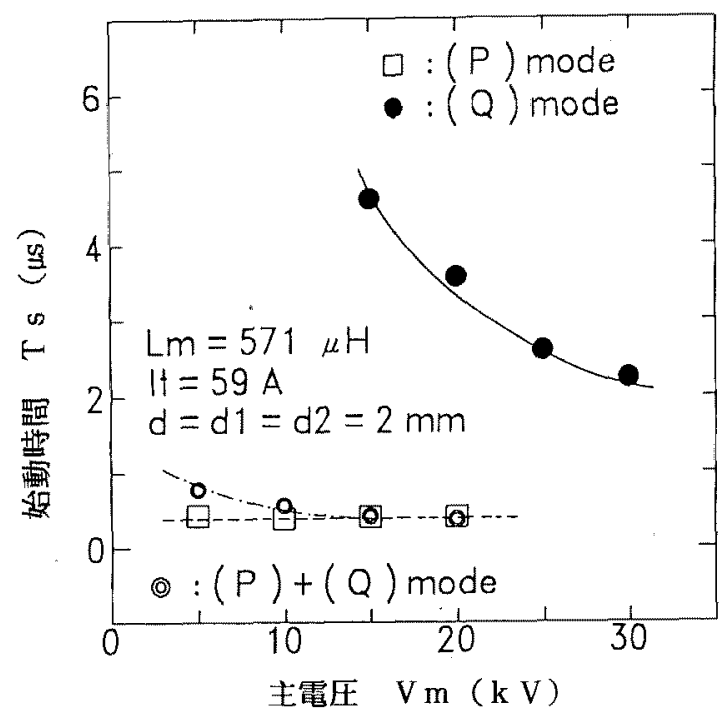

（a）始動時間と主電圧の関係

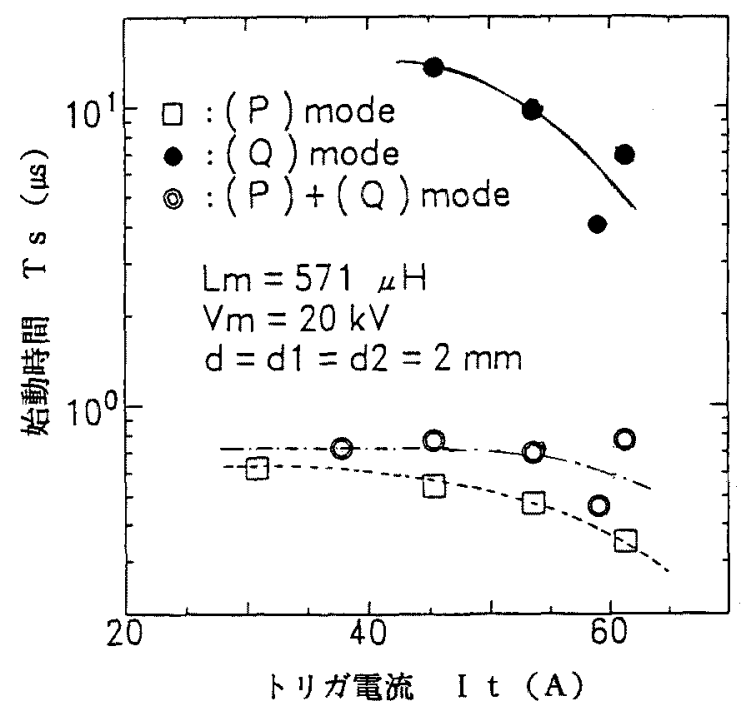

（b）始動時間とトリガ電流の関係

図9 始動時間と主電压, トリガ電流の関係 Fig. 9. Switching time of a TVG as a function of main voltage and trigger current.

とともに，始動時間は短くなる。（P）+（Q）モードの 場合にも，類似の傾向が見られる。

以上の結果は，図1の（P）と（Q）モードの亚列接続 の場合の結果である。（R）と（ $\mathrm{S}$ ) モードの並列接繶の 場合にも，(P) と（Q）モ一ドの並列接続の場合と類似 の結果を得ている。

\section{4. まとめ}

以上の結果を要約すると，次のようになる。

（1）逆極性並列接続した各真空トリガキャッブを流れる 電流は，半波每に交互に流れる場合が多く観測された。し
かし, 全電流は減衰振動電流となった。

（2）逆極性並列接続した真空トリガギャップの始動確率 は，陰極側からトリガした真空トリガギャップの始動確率 に一致した。陰極侧トリガの始動確率は，本実験の範柬内 で,トリガ電流，主電極ギャップ長に関係なく，100\%を 示した。陽極側からトリガした真空トリガギャップの始動 確率は，トリガ電流が大きく，主電極ギャップ長が短いほ ぞ，高い。トリガ電流10.31 以下，または主電極ギャップ 長 $3 \mathrm{~mm}$ 以上では，逆極性並列接続した陰極側トリガのギャ ップのみしか始動しない。

（3）逆極性並列接続した真空トリガギャップの始動時間

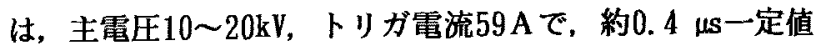
を示した。この始動時間は，始動時間の短い陰極侧からト リガした単体ギャップの始動時間に近い。

終りに，本実験に協力された本学技官伊藤 告氏ならび に修士 2 年の渡刃圭一君に感謝する。

(平成10年 5 月 25 日受付, 平成 10 年 11 月 30 日再受付)

\section{文 献}

(1) E. Kuffel and M. M. Bera: "Breakdown in Triggered Spark Gaps in Air ", IEEE Trans. Pow. App. and Syst. PAS-87, 1628(1968).

(2) 林, 林尾:「気中ギャップスイッチと真空スイッチ の始動特性」，電学誌, 86, 4, 581-590(1966).

(3) J. M. Lafferty : "Triggered Vacuum Gaps ", Proc. IEEE, 54, 23-32(1966).

(4) H. Arita, K. Suzuki and Y. Kurosawa: " Switching Characteristics of the Triggered Vacuum Gap for a High-Repetition-Rate Pulse-Power Source”, IEEE Trans. on Plasma Sci., 20, 76-79(1992).

(5) R. A. Dougal, G. Morris and G. D. Volakakis : "LowLoss, High-Repetition-Rate Vacuum Switching", IEEE Trans., Plasma Sci., PS-19, 976-988(1982).

(6) F. T. llarren et a1.: "Vacuum Switch Trigger Delay Characteristics ", IEEE Trans., Plasma Sci.. PS-10, 298-301 (1982).

(7) PP Gervadis and RSN Rau:" Firing Characteristics of a Simple Coaxial Triggered Vacuum Gap”, J, Phys. D:App1. Phys. , 14, 867(1981).

(8) L. M. J. Vries and G. C. Damstra:" A Reignition Installation with Triggered Vacuum Gaps for Syntetic Fault Interruption Testing ", IEEE Trans. Pow. Syst. , PWRD-1, 75-80(1986).

(9) G. A. Farral:" Low Voltage Firing Characteristic of Triggered Vacuum Gap ", IEEE Trans. Elect. Devices, $\mathrm{ED}-13,432-438$ (1966).

(10) G. R. Govinda Raju, R. Hackam and F. A. Benson : "Breakdown Mechanism and Electrical Proper- 
ties of Triggered Vacuum Gaps ", J. Appl. Phys., 47, 1310-1317(1976).

(11) A. J. Green and C.Christopoulos:" Plasma Buil up and Breakdown Delay in a Triggered Vacuum Gap ", IEEE Trans. , Plasma Sci. , PS-7, 111-115(1979).

(12) H. Samaulah, K. Itagaki, H. Ki tamura and $\Lambda$. Sugawara : "Switching Characteristics of Two SeriesConnected Triggered Vacuum Gaps ", 電学論, 115A, 8, 719-725(1995).

（13）营原，ハザイリン，板垣，喜多村：「両主電極にト リガ電極をもつ真空トリガギャップの始動特性」, 電学論, 116-B, 1,87-92(1996).

(14) H. Samaulah, K. Itagaki, A. Sugawara, T. Maruyama and H. Kitamura:" Switching Characteristics of Two Parallel-Connected Triggered Vacuum Gaps”, 電学 論, 117-B, 3, 346-353(1997).

(15) G. Frind, J. J. Carroll and C. P. Goody : "Recovery Time of Vacuum Interrupters", IEEE Trans., Pow. App. and Syst., PAS-101, 775-781(1982).

(16) G. A. Fara11:" Recovery of Dielectric Strength After Current Interruption in Vacuum ", IEEE Trans. , Plasma Sci. , PS-6, 360-369(1978).

(17) J. D. Cobine and L. E. Lee: "Recovery Characteristics of a Triggered-Vacuum Gap at High $\mathrm{Cu}^{-}$ rrent ”, J. Appl. Phys. , 42, 4865-4869(1971).

板垣 厚一（正員） 1938年 4 月 7 日生まれ。62年

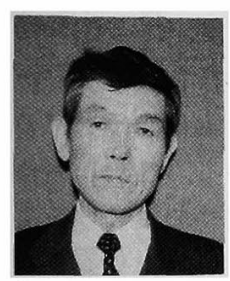

3 月新潟大学工学部電気工学科卒業。同 年 4 月（株）建上製作所入社。長岡工場 に勤務。65年 1 月新潟大学工学部電気工 学科助手, 77 年 4 月同大助教授, 85 年 6 月同教授、現在に至る。工学博士。主と して, 真空放電および風力発電の研究に 従事。日本風力エネルギー協会, 日本雪 工学会会員。

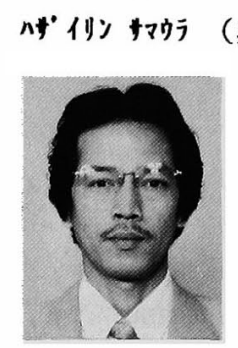

（非会員）

1958年 7 月22日生まれ。84 F 3 月 Brawijaya大学 (インドネシア) 電 気工学科卒業。94年 3 月新潟大学大学院 工学研究科修士課程修了。97年 3 月新渴 大学自然科学研究科博士課程修了。主と して, 真空トリガギャップの始動特性の 研究に従事。現在, Tridinanti大学勤務。 博士 (工学)。

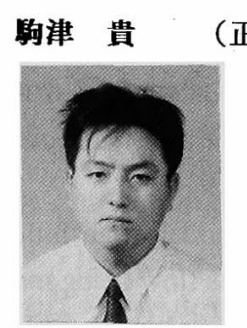

(正員)

1974年 3 月 16 日生まれ。96年 3 月新潟大学工学部電気電子工学科卒業。 98年 3 月新渴大学大学院自然科学研究科 修士課程修了。主として真空トリガギャ ップの研究に従事。現在, (株) トーエ ネック勤務。

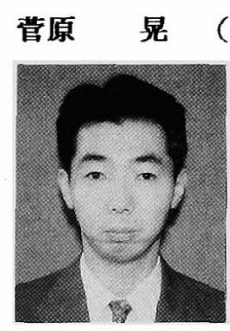

（正員）

1964年11月11日生まれ。89年

3 月新渴大学工学部電気工学科卒業。9 1 年 3 月新潟大学大学院工学研究科修士課 程修了。94年 3 月新渴大学大学院自然科 学研究科博士課程修了。同年 4 月新潟大 学工学部電気電子工学科助手, 97 年 4 月 同譜師, 98年11月同助教授、現在に至る。 博士 (工学)。主として真空中の放電現 象に関する研究に従事。日本物理学会,

プラズマ・核融合学会会員。

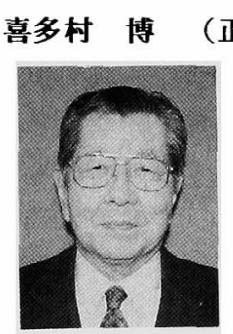

1931年 7 月 23 日生まれ。 55 年 3 月新渴大学工学部電気工学科卒業。5 6 年 4 月新捣大学工学部電気工学科助手, 62 年 4 月同講師, 64 年 8 月同助教授, 75 年 4 月同教授。高電圧工学を担当し, 主 として、気中おょび真空中の放電現象に 関する研究に従事。現在, 新潟工科大学 教授。工学博士。 